\title{
Peptide-targeted dendrimeric prodrugs of 5-aminolevulinic acid: \\ A novel approach towards enhanced accumulation of protoporphyrin IX for photodynamic therapy
}

\author{
K. M. Tewari, ${ }^{\text {a }}$ R. Dondi, ${ }^{\text {a E. Yaghini, }}{ }^{\text {b C. Pourzand, }},{ }^{\mathrm{a}}$ A. J. MacRobert, ${ }^{\mathrm{b}}$ I. M. Eggleston ${ }^{\mathrm{a} *}$ \\ ${ }^{a}$ Department of Pharmacy and Pharmacology, University of Bath, Bath BA2 7AY, UK \\ ${ }^{b}$ Division of Surgery and Interventional Science, University College London, Royal Free Campus, Rowland Hill \\ Street, London NW3 2PE, UK.
}

\section{Highlights}

- Efficient synthesis of peptide-targeted prodrug with multiple ALA units

- Prodrug shows sustained and enhanced PpIX production vs ALA

- Enhanced PpIX production vs non-targeted species in MDA-MB-231 cells

\begin{abstract}
Photodynamic therapy (PDT) is a promising approach for the targeted treatment of cancer and various other human disorders. An effective, clinically approved approach in PDT involves the administration of 5-aminolevulinic acid (ALA) to generate elevated levels of the natural photosensitiser protoporphyrin IX (PpIX). The development of prodrugs of ALA is of considerable interest as a means to enhance the efficiency and cell selectivity of PpIX accumulation for PDT applications. In this work a novel peptide-targeted dendrimeric prodrug of 5-aminolevulinic acid (ALA) 13 was synthesised which displays nine copies of ALA on a core structure that is linked to a homing peptide for targeted delivery to a specific cancer cell type. The synthesis was accomplished effectively via a flexible, modular solid phase and solution phase route, using a combination of solid phase peptide synthesis and copper-catalysed azide-alkyne cycloaddition chemistry. The prodrug system shows a sustained and enhanced production of protoporphyrin IX (PpIX) in the MDA-MB-231 cell line that over-expresses the epidernal growth factor receptor (EGFR+) in comparison to equimolar ALA and the corresponding non-targeted ALA dendrimer (nine copies of ALA). This study provides a proof of concept for the development of a new generation of prodrugs for ALA-based photodynamic therapy that can deliver an enhanced ALA payload to specific tissue types.
\end{abstract}




\section{Graphical abstract}

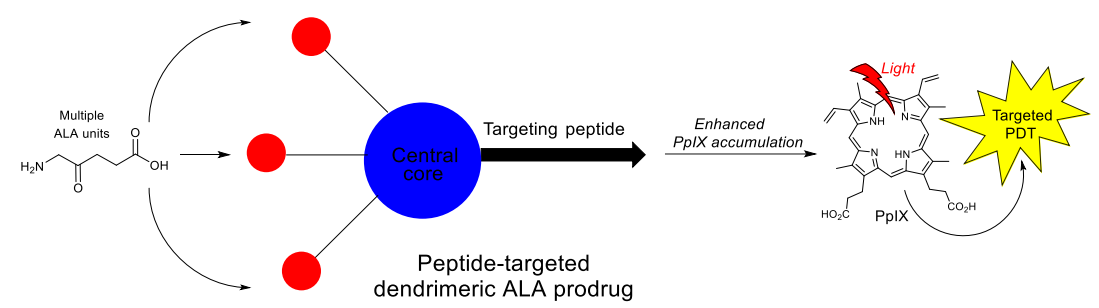

\section{Keywords}

Photodynamic therapy, aminolevulinic acid, protoporphyrin IX, fluorescence diagnosis, prodrug, click chemistry, peptide 


\begin{abstract}
Abbreviations
Age-related macular degeneration (AMD); aminolevulinic acid (ALA); European Medicines Agency (EMA); epidermal growth factor receptor (EGFR); US Food and Drug Administration (FDA); fluorescence photodiagnosis (PDD); photodynamic therapy (PDT); protoporphyrin IX (PpIX), solid phase peptide synthesis (SPPS).
\end{abstract}




\section{Introduction}

Photodynamic therapy (PDT) is a minimally-invasive therapeutic technique, which depends upon the combined action of three components: light, molecular oxygen, and a photosensitiser [1]. Targeted destruction of diseased tissue in PDT is achieved by the generation of cytotoxic reactive oxygen species such as singlet oxygen, that damage cellular components. Since these effects can be limited to the area of tissue that is illuminated and take place only during illumination, PDT has attracted particular interest in oncology for treatment of solid tumours [2,3], as well as for the treatment of non-malignant conditions such as age-related macular degeneration (AMD), superficial acne [4] and dental caries [5].

Protoporphyrin IX is a natural photosensitiser whose formation is the penultimate stage in the biosynthesis of heme (Scheme 1). Accumulation of PpIX may be induced by the administration of its biosynthetic precursor 5-aminolevulinic acid (ALA) - this is the principle of ALA-PDT [6] and also fluorescence photodiagnosis (PDD) using administered ALA [7, 8]. The production of ALA in heme biosynthesis is normally tightly controlled by heme itself functioning as a feedback inhibitor of the enzyme, ALA synthase, but this mechanism is bypassed by introduction of exogeneous ALA, and build-up of PpIX results due to slow conversion of the latter to heme by insertion of a ferrous ion into its tetrapyrrole core [7].
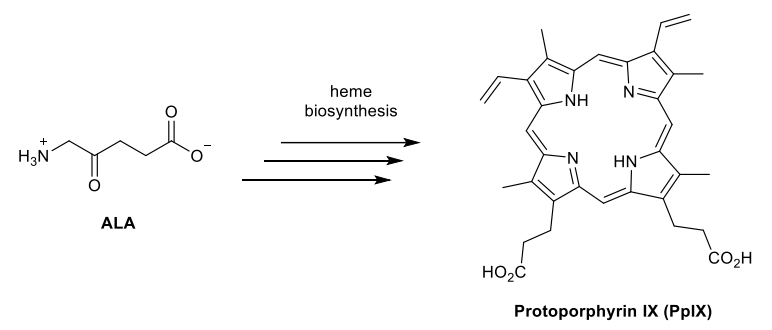

Scheme 1: Bioconversion of ALA to PpIX via the heme cycle.

Metabolic conversion of exogenous ALA into photosensitising concentrations of PpIX is relatively fast, requiring only 1-3 h. Unlike many classical tetrapyrrole-based photosensitisers (i.e porphyrin-like), ALA can be administered both topically and systemically, and when applied topically, the photosensitized area may be confined to the site of application with no systemic effects. Moreover, the exposure of normal tissue upon irradiation is effectively restricted in ALA-PDT by rapid photobleaching of PpIX upon reaction with singlet oxygen, while general systemic patient photosensitivity is restricted to less than 2 days [6]. These advantages have led to the development and approval of ALA-PDT as a first line clinical approach for the treatment of cancerous and precancerous skin lesions e.g Bowen's disease, basal skin carcinomas, and actinic keratosis that would otherwise require significant conventional surgery [9], most recently with the application of the UVA component of sunlight for activation of PpIX (daylight PDT) [10-12]. ALA-induced PpIX production is now an established tool in PDD and has also recently been approved by the FDA and EMA for fluorescence-guided resection of malignant tumours in the brain [13, 14].

Despite this encouraging background, the use of ALA for PDT and PDD presents some challenges. At physiological pH, ALA is a zwitterion, which results in poor lipid solubility and limits its passage through biological barriers such as cellular membranes $[15,16]$. To address this, many prodrugs of ALA have been studied to offset the hydrophilic nature of ALA itself, enhance stability at physiological $\mathrm{pH}$, and to improve targeting of cancerous cells $[17,18]$. The formation of lipophilic esters as in the clinically approved methyl ester (Metvix) and hexyl ester (Hexvix), has been shown to be highly effective for the enhancement of ALA uptake, but the use of simple ALA-esters presents a challenge with respect to specificity, causing a nonspecific distribution of ALA in all cell types post administration of the prodrugs [19]. 
Recent studies on ALA prodrugs have focused on the design of small molecule prodrugs or smart nanosystems that release ALA effectively within targeted cells through a range of specific stimuli. This includes exploiting the elevated levels of phosphatase or $\beta$-glucuronidase activity in certain tumour cells [20,21], or changes in intracellular glutathione concentration [22], as well as the development of $\mathrm{pH}$-responsive systems from which ALA is released upon delivery to the lowered $\mathrm{pH}$ environment of endosomes/lysosomes [23, 24]. We have previously described the synthesis and evaluation in vitro and in vivo of a range of simple dipeptide prodrugs of ALA that both show enhanced cellular uptake relative to ALA itself and are cleaved by cell-line specific protease activities to produce PpIX [25-28]. Furthermore, encouraging results have also been obtained with more elaborate ALA peptide prodrugs [29-33] developed by ourselves and other laboratories. These studies suggest that targeting of ALA with tumour-homing peptides may provide an effective way to achieve enhanced accumulation and PDT effects, as has been widely seen with more conventional photosensitisers and their peptide conjugates (for example [34-39]).

A complementary innovation for the improved delivery of ALA has been described by Battah et al. [40], using dendrimer systems. In these molecules, multiple units of ALA are connected to a simple core structure by ester linkages, and uptake is primarily via endocytic pathways (e.g. micropinocytosis) [41], rather than being driven by enhanced lipophilicity or active transport mechanisms [26]. Although such systems lack a specific cell-targeting motif, they have been shown to provide both an enhanced and sustained production of PpIX compared to equivalent doses of free ALA. ALA dendrimers have been shown to be effective for both in vitro [41-44] and in vivo PDT applications [45] as well as in PDD of tumours [46].

In this study we present a proof of concept for a novel prodrug approach towards enhanced targeted ALA delivery for PDT. This combines the potential of dendrimeric ALA ester derivatives for delivering a higher payload of ALA in a single prodrug entity with a peptide address unit, in order to produce a prodrug system capable of delivering multiple ALA units selectively to a given cell type for tumour imaging or therapy. 


\section{Results and Discussion}

\subsection{Prodrug design}

The essential structure of our prodrug system consists of three elements: a central core, multiple sets of ALA units (ALA dendrons), and a chosen targeting peptide (Figure 1). Both the peptide and the ALA units are attached independently to the core molecule. For maximum flexibility, we envisaged preparation of the peptide component by solid phase synthesis followed by the attachment of the ALA units via copper-catalysed azide-alkyne (CuAAC) click chemistry (see below) with suitable complementary functionalities installed on the core and the ALA dendrons. As a prototype, a system for the delivery of nine ALA units was chosen along with a hexapeptide targeting sequence which has been previously shown to provide efficient targeting of porphyrin and phthalocyanine photosensitisers to tumour cell lines that overexpress the epidermal growth factor receptor (EGFR) [47-49].

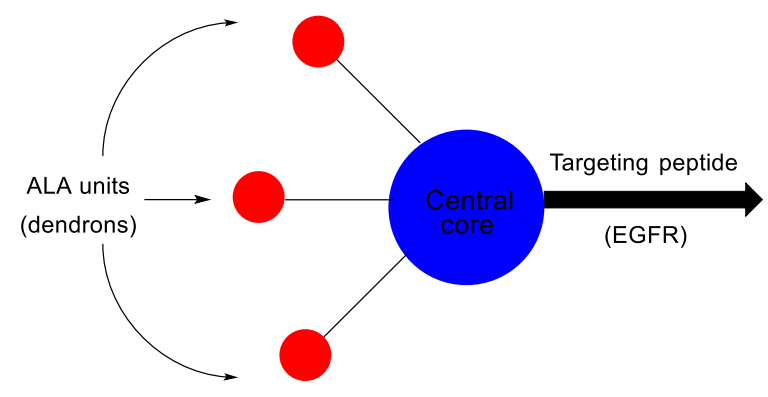

Figure 1. Concept of a peptide-targeted dendrimeric prodrug of ALA.

\subsection{Synthesis of a ligatable ALA dendron unit}

The readily available amino triol derivative 1 employed by Battah et al. [40] was chosen as the basis for the required ligatable ALA dendrons incorporating three ALA units. As shown in Scheme 2, selective N-acylation of 1 with pentynoic acid was achieved in 66\% yield, using mild carboxyl activation via in situ mixed anhydride formation with EEDQ, as described by Feast [50]. The final ligatable ALA dendron 4, was then obtained in high yield by DMAP-catalysed esterification of the hydroxyl functions with Boc-ALA 3, using EDC as the coupling agent.

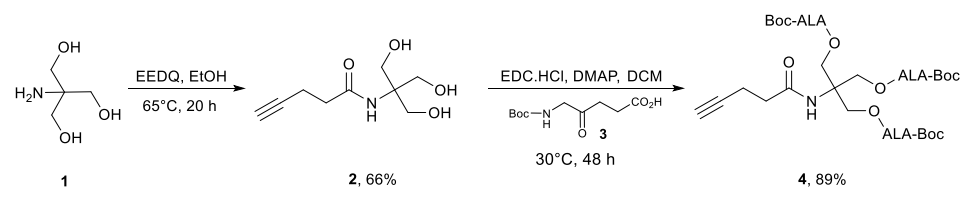

Scheme 2. Synthesis of ligatable ALA dendron 4

\subsection{Synthesis of non-targeted dendrimer prodrug}

In order to allow the effectiveness of the proposed targeting approach to be assessed, the relevant non-targeted ALA dendrimer system was first prepared as shown in Scheme 3. The core molecule chosen for our prototype 9-ALA system was the known trivalent azido derivative 5 which was prepared according to the method of Amaral et al. [51] (see Supplementary material). The carboxylic acid function of $\mathbf{5}$ was expected to provide a straightforward means of linking this intermediate to a targeting peptide during solid phase assembly (see 2.4). Reaction of 5 (1 eq) and alkyne-functionalised dendron 4 (6 eq) under classic CuAAC 
click coupling conditions $\left(\mathrm{CuSO}_{4}\right.$, sodium ascorbate [52]) in $\mathrm{DMSO} / \mathrm{H}_{2} \mathrm{O} / \mathrm{tBuOH}$ led to complete consumption of 5 after $72 \mathrm{~h}$ at room temperature as judged by HPLC, with clean formation of a single new species, the expected ligation product 6 (see Supplementary material), which was subsequently isolated in $50 \%$ yield. The structure of 6 was confirmed by ${ }^{1} \mathrm{H}$ NMR (showing the expected integration of $3 \mathrm{x} \mathrm{CH}$ signals for the triazole units), ${ }^{13} \mathrm{C}$ NMR and mass spectrometry. The Boc protecting groups from 6 were then finally removed by treatment with 50\% TFA in DCM for 30 min to give the non-targeted prodrug 7 as the TFA salt in good yield.

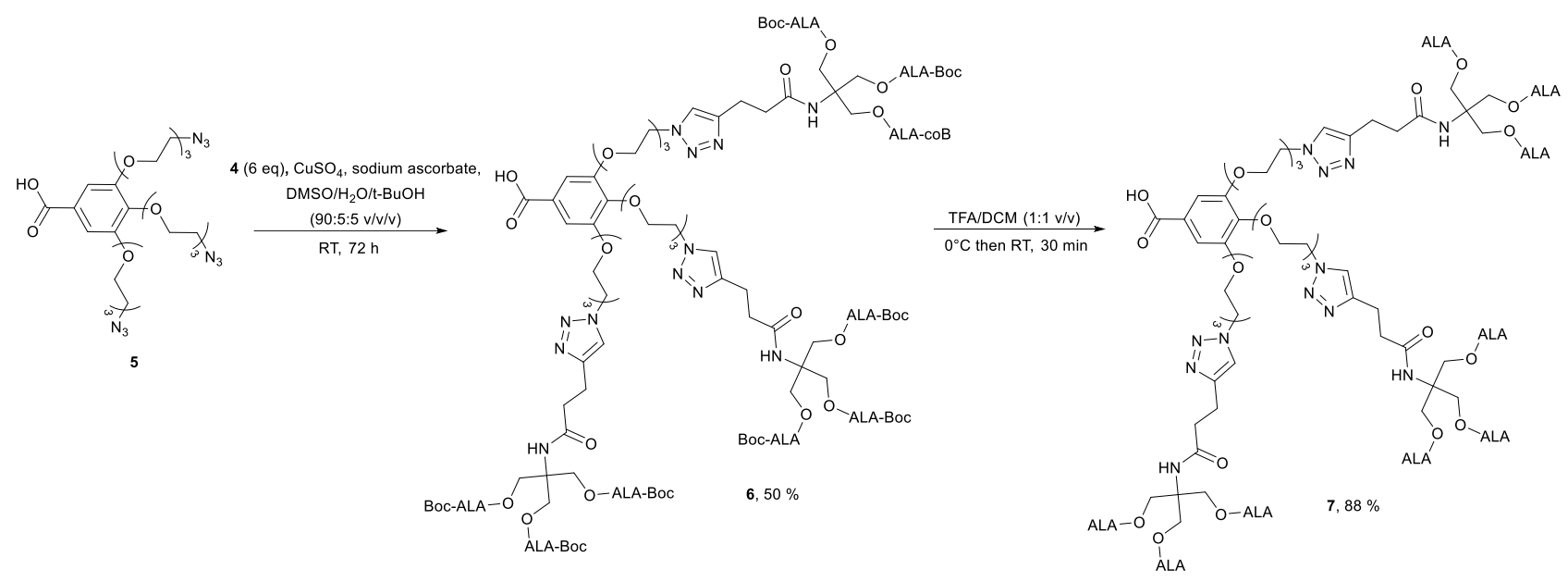

Scheme 3. Synthesis of non-targeted ALA dendrimer 7 via CuAAC chemistry.

\subsection{Synthesis of peptide-targeted dendrimer prodrug}

The chosen targeting peptide LARLLT 9 was originally identified by Song et al. from computational screening of a virtual peptide library [53] and has been shown to target the EGF receptor in both in vitro and in vivo studies. We selected it for this investigation as studies by Vicente and coworkers [47-49] have clearly demonstrated that attachment of this peptide to tetrapyrrole photosensitisers results in significantly enhanced uptake in EGFR-overexpressing cells compared to that observed with the unconjugated photosensitisers. As described in Section 2.1, the synthesis of the desired peptide-targeted derivative 13 was attempted using a combination of solid phase and solution chemistry, starting from the peptide component (Scheme 4). The peptide component was first assembled on 2-chlorotrityl resin by standard Fmoc solid phase peptide synthesis, then it was acylated on the N-terminus with the trivalent azido acid $\mathbf{5}$ using HATU activation. Complete acylation of the resin-bound intermediate 8 to the resin-bound derivative 10 was verified by negative Kaiser test [54] and the intermediate azido-functionalised peptide 11 was obtained in 54\% yield following cleavage of the resin with TFA/TIS/ $\mathrm{H}_{2} \mathrm{O}(95: 2.5: 2.5 \mathrm{v} / \mathrm{v} / \mathrm{v})$, with no remaining unacylated targeting peptide 9 detectable by HPLC or MS analysis.

For the critical multiple click coupling reaction between $\mathbf{1 1}$ and $\mathbf{4}$, a variety of copper (I) sources were screened [55, 56], with the most effective being found to be copper (I) triflate. benzene complex [57]. When this reaction was carried out in DMSO at room temperature, HPLC analysis after $36 \mathrm{~h}$ confirmed complete disappearance of $\mathbf{1 1}$ and clean formation of the anticipated Boc-protected conjugate 12, with no detectable amounts of mono or di-triazole conjugates. Following purification by semipreparative HPLC, 12 was isolated in 69\% yield, and then converted to the final prodrug 13 by treatment with TFA/DCM (Scheme 4). The efficiency of the click assembly of the ALA dendrons $\mathbf{4}$ onto the peptide-linked trivalent azido core $\mathbf{1 1}$ could be further enhanced by carrying out the transformation under microwave heating conditions. There are many reports of successful 
and high-yielding preparations of peptidomimetics via CuAAC using microwave activation, either involving solution [58] or solid phase chemistry [59,60] and sometimes where reactions under conventional heating are ineffective. It has also been successfully applied for the preparation of peptide-tagged tetrapyrrole derivatives for PDT applications [61]. In this case, when the click reaction between $\mathbf{1 1}$ and $\mathbf{4}$ was carried out under microwave heating $\left(10-15 \mathrm{~W}, 70^{\circ} \mathrm{C}\right)$, a highly efficient conversion to 12 was again observed (Figure 2), with 13 being isolated in a comparable yield to the room temperature reaction, but with the reaction time reduced to only $15 \mathrm{~min}$. Removal of the Boc protecting groups as before then gave $\mathbf{1 1}$ in an excellent yield.

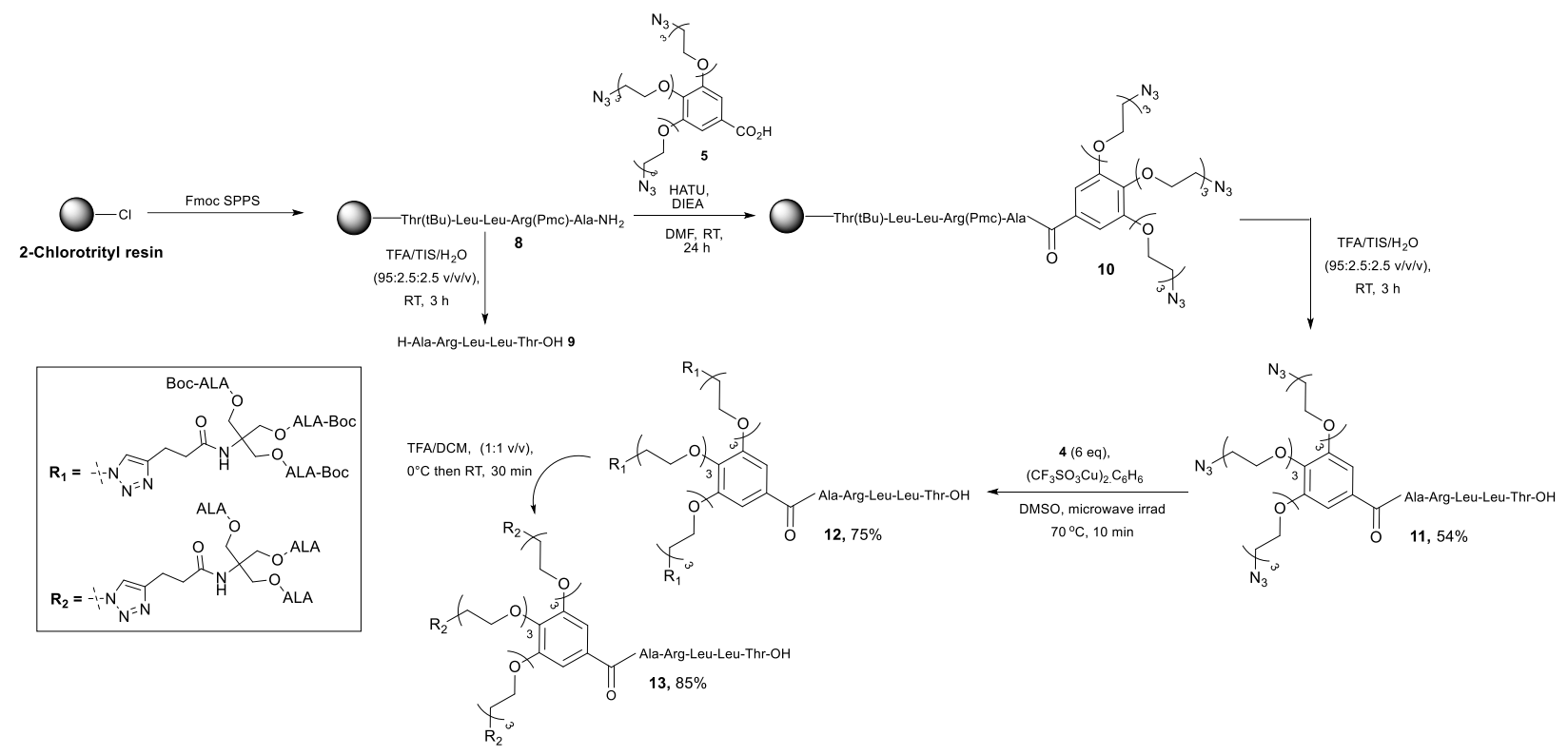

Scheme 4. Modular solid phase peptide synthesis and solution click coupling strategy for preparation of peptide-targeted dendrimeric ALA prodrug 13. 

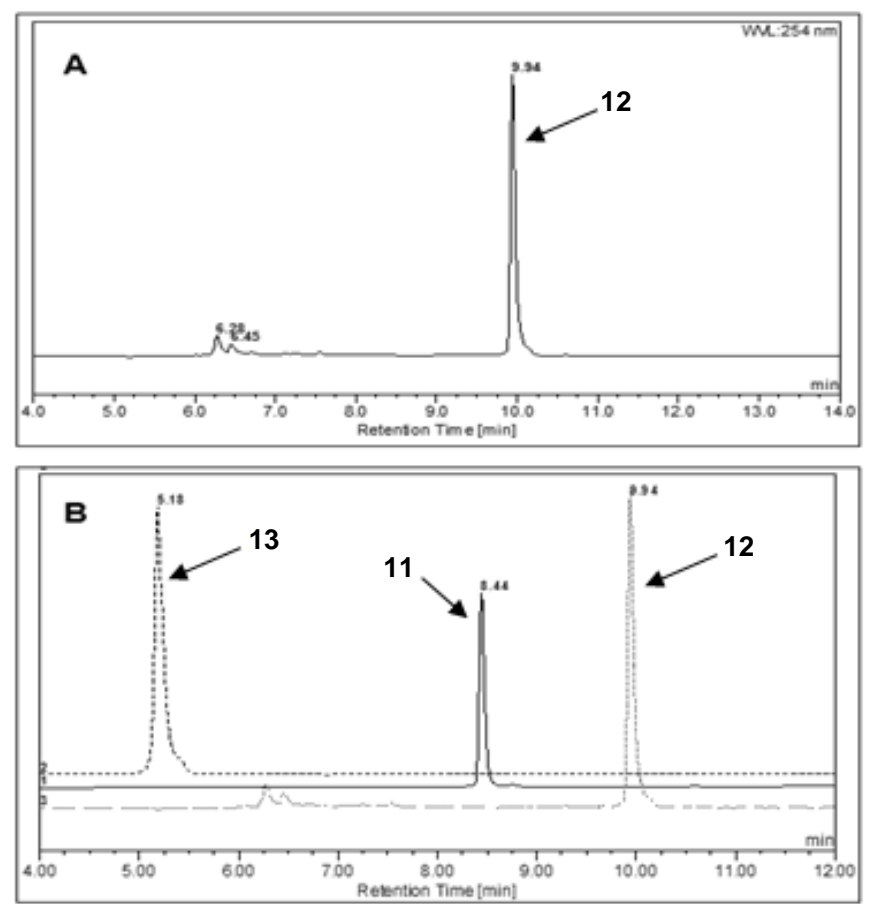

Figure 2. HPLC chromatograms for microwave-assisted click coupling in the synthesis of peptide-targeted ALA dendron 13. (A) crude reaction mixture for peptide-targeted ALA dendron (Boc-protected) 12; (B) overlay of HPLC chromatograms for purified peptidetargeted ALA dendron (Boc-protected) 12, peptide-azido spacer 11, and the final deprotected conjugate 13.

\subsection{Time-course fluorescence studies with ALA prodrugs}

The build-up of PpIX fluorescence induced by the ALA dendrimer, 7 (9-ALA units, non-targeted), and 13 (EGFR targeting with 9 ALA units) was investigated in MDA-MB-231 cells (EGFR-overexpressing breast cancer cell line). The two prodrug derivatives were compared alongside free ALA at $1.0 \mathrm{mM}$, with the concentrations of $\mathbf{7}$ and $\mathbf{1 3}$ being adjusted for the number of ALA units. Higher effective concentrations of $\mathbf{7}$ and $\mathbf{1 3}$ (up to 9-fold greater, based on number of ALA units) were also studied to investigate any possible dark toxicity effects. The PpIX fluorescence obtained with $\mathbf{7}$ and $\mathbf{1 3}$ was measured at the end of 4,8 and $24 \mathrm{~h}$ and the results are shown in Figure 3. 

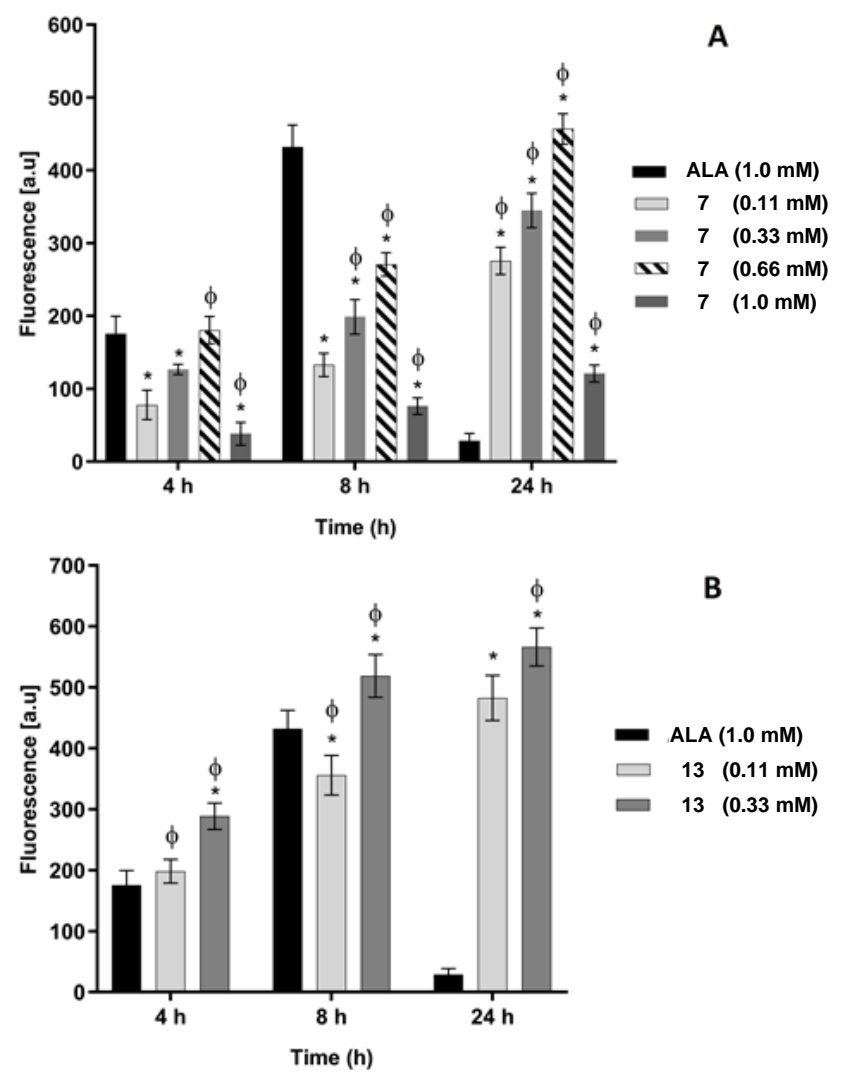

Figure 3. ALA-induced PpIX generation from 7 and 13 in MDA-MB-231 cells. A. MDA-MB-231 cells were treated with $7(0.11 \mathrm{mM})$ and were incubated at $37{ }^{\circ} \mathrm{C}$ in the dark. Fluorescence readings were taken at 4,8 and $24 \mathrm{~h}$ intervals and the results were compared with an effective equimolar concentration of ALA (1.0 mM). Additional experiments with a higher concentration of ALA prodrug 7 were also included in this study $(0.33,0.66$ and $1.0 \mathrm{mM})$. B. MDA-MB-231 cells were treated with $\mathbf{1 3}(0.11 \mathrm{mM})$ and the same protocol was followed as for A. above. A higher concentration of $\mathbf{1 3}(0.33 \mathrm{mM})$ was also included in this study. Results are expressed as mean \pm SD $(n=3)$. Data were analysed using paired and unpaired t-tests (see Section 4.9) and statistically significant differences between groups of data $(p<0.05)$ are indicated by $\star$ and $\phi$ respectively, where $\star$ denotes a significant difference from the ALA treated cells, and $\phi$ denotes a significant difference from ALA prodrug treated cells $\mathbf{7}$ and $\mathbf{1 3}$ at different concentrations.

From the results, it can be deduced that both the targeted and non-targeted ALA dendrimers $\mathbf{7}$ and $\mathbf{1 3}$ at $0.11 \mathrm{mM}$ produce a sustained release of PpIX in comparison to the effective equimolar concentration of ALA, where a sharp decline is observed at the end of $24 \mathrm{~h}$. A similar release pattern was also observed with the higher concentrations studied for $7(0.33$ $\mathrm{mM}$ and $0.66 \mathrm{mM})$ and $\mathbf{1 3}(0.33 \mathrm{mM})$. These results are in overall agreement with previous work by Casas et al. where sustained production of ALA-induced PpIX was observed with a non-targeted 18-ALA dendron over $24 \mathrm{~h}$, and where basal values were not reached until 48 h [41, 44]. The sharp decrease in PpIX generation after $24 \mathrm{~h}$ with ALA alone may be attributed to natural metabolism of PpIX through the action of ferrochelatase (to produce heme) and subsequently heme oxygenase, as well as efflux through PpIX transporters, such as the ATP-binding cassette sub-family G member 2 (ABCG2) [62]. The sustained production of PpIX from 7 and 13 after $24 \mathrm{~h}$ on the other hand may be explained by slow release of ALA from the dendrimer structures through hydrolysis of the internal ester linkages [46].

ALA-induced PpIX fluorescence obtained for 7 indicated at first a lower production of PpIX at doses of 0.11, 0.33 and $0.66 \mathrm{mM}$ at the end of $8 \mathrm{~h}$ in comparison to free ALA $(1.0 \mathrm{mM})$, although at the highest dose of $0.66 \mathrm{mM}, 7$ did show a 
similar PpIX fluorescence to ALA at the end of $4 \mathrm{~h}$ (60\% at the end of $8 \mathrm{~h}$ incubation). This represents an effective 6-fold greater ALA payload compared to the same concentration of free ALA. Increasing the dose of 7 to $1.0 \mathrm{mM}$ resulted in a reduction of PpIX fluorescence at all time points, suggesting some dark toxicity effects due to the released ALA. The final level of PpIX fluorescence observed for 7 at $1.0 \mathrm{mM}$ after $24 \mathrm{~h}$ was nonetheless still significantly greater than that observed for the same, non-adjusted concentration of free ALA. At the equivalent concentration of free ALA (9 mM), very significant toxicity would be expected in the absence of light [63]. For the EGFR-targeted ALA derivative 13, the results are even more striking. Firstly, upon incubation of the EGFR(+) MDA-MB-231 cells with an effective equimolar concentration of prodrug compared to free ALA $(0.11 \mathrm{mM}$ vs $1.0 \mathrm{mM}$ of free ALA), a comparable level of PpIX fluorescence was observed after only $4 \mathrm{~h}$, and at $24 \mathrm{~h}$ PpIX production was not only sustained, but some 10 times greater than the free ALA value. At a higher concentration of $\mathbf{1 3}$ ( $0.33 \mathrm{mM}$ prodrug), the PpIX production is again sustained over a $24 \mathrm{~h}$ period, and moreover is superior to that obtained with $1.0 \mathrm{mM}$ free ALA after both $4 \mathrm{~h}$ and $8 \mathrm{~h}$ incubation. Finally, comparison of Figures $3 \mathrm{~A}$ and $3 \mathrm{~B}$ shows that at a concentration of $0.11 \mathrm{mM}$, PpIX production is consistently up to twofold greater at $4 \mathrm{~h}, 8 \mathrm{~h}$, or $24 \mathrm{~h}$ for the EGFR-targeted derivative $\mathbf{1 3}$ relative to the non-targeted derivative 7 (see Supplementary Material, Table S1). Overall, these results confirm not only the effectiveness of the designed dendrimer structure of $\mathbf{7}$ and $\mathbf{1 3}$ for the delivery of an enhanced ALA payload relative to the free prodrug, but more importantly indicate a targeting effect associated with the attached peptide in 13; the enhanced production of PpIX is consistent with the elevated levels of photosensitiser uptake previously observed in EGFR-overexpressing cells for conventional photosensitisers linked to this peptide unit [49].

\subsection{Photocytotoxicity studies}

Having established that both $\mathbf{7}$ and $\mathbf{1 3}$ effectively produced PpIX in MDA-MB-231 cells, the effectiveness of both the targeted and non-targeted prodrugs for PDT was investigated. Phototoxicity studies were carried out by incubating MDAMB-231 cells for $4 \mathrm{~h}$ at $37^{\circ} \mathrm{C}$ either with ALA at $1.0 \mathrm{mM}, 7$ or 13 at concentrations of $0.11,0.33$, or $0.66 \mathrm{mM}$ representing equimolar, three or six-fold effective ALA payloads. The cells were subsequently irradiated with a UVA light source for different time intervals up to $1.5 \mathrm{~min}$. Control cells were treated identically except that they were either not treated with $\mathbf{7}$ and $\mathbf{1 3}$ (or free ALA), or not irradiated. Statistical analysis was done at the end of study by plotting the percentage cell viability obtained for the investigated compounds with respect to control cells (without any compounds). The results shown in Figure 4 confirm that in the absence of irradiation, no toxicity or reduction in viability is observed for concentrations of the non-targeted derivative 7 up to $0.66 \mathrm{mM}$. At this concentration, following $4 \mathrm{~h}$ incubation, the percentage reduction in cell viability observed upon irradiation is comparable to that seen with $1.0 \mathrm{mM}$ ALA, consistent with the levels of PpIX production observed above. For the EGFR-targeted derivative 13, however, even at an equivalent effective concentration to that of free ALA, a significantly enhanced reduction in cell viability is observed at the shortest irradiation time, again reflecting the enhanced peptide-mediated delivery of ALA and PpIX production upon only $4 \mathrm{~h}$ incubation. A small enhancement in photocytotoxicity was observed with $\mathbf{1 3}$ when the concentration was increased to $0.33 \mathrm{mM}$, again consistent with the previously observed levels of PpIX production relative to 1.0 mM free ALA. The results also confirm that at this concentration of $\mathbf{1 3}$, three times the concentration of free ALA employed, there is no toxicity in the absence of light. 

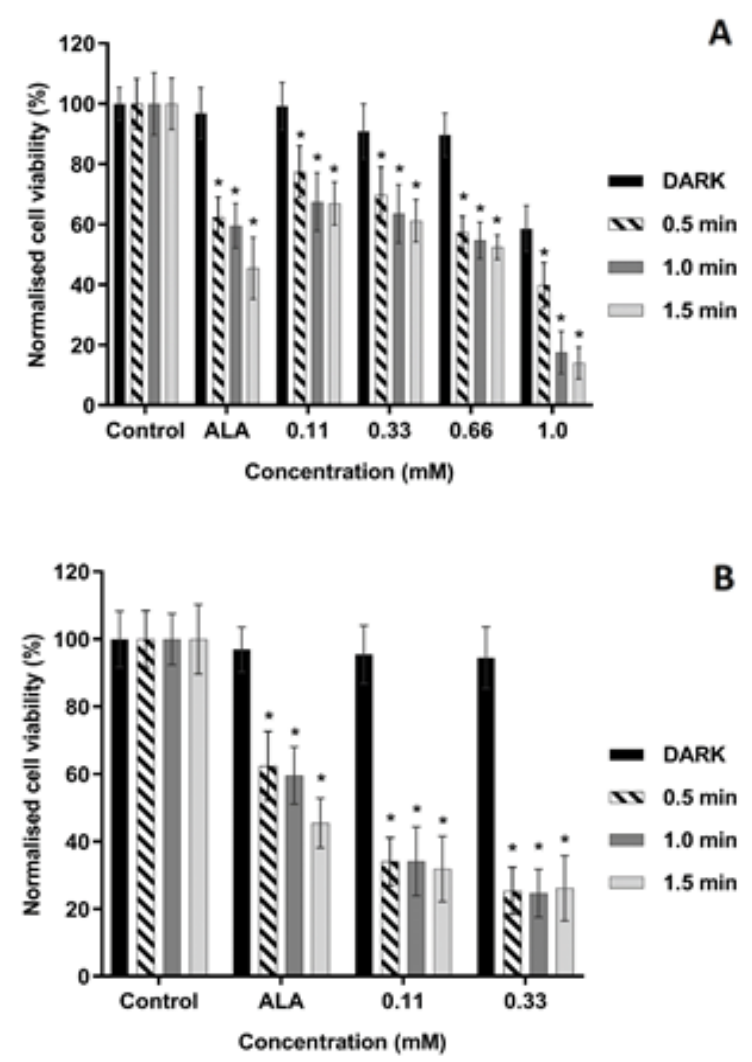

Figure 4. PDT effect of $\mathbf{7}$ and $\mathbf{1 3}$ on MDA-MB-231 cells after incubation for 4 h. A. MDA-MB-231 cells were treated with ALA dendrimer $7(0.11 \mathrm{mM})$ and were incubated for $4 \mathrm{~h}$ at $37{ }^{\circ} \mathrm{C}$ in the dark. Cells were illuminated with UVA lamp for $0.5,1.0$ and 1.5 min. MTT analysis was carried out $24 \mathrm{~h}$ after light illumination and the results were compared with equimolar doses of ALA (1.0 mM). Higher concentrations of $7(0.33,0.66$ and $1.0 \mathrm{mM})$ were also included in this study. B. MDA-MB-231 cells were treated with EGFR targeted ALA-dendrimer $\mathbf{1 3}(0.11 \mathrm{mM})$ and the same protocol was followed as for A. above. A higher concentration of $\mathbf{1 3}(0.33 \mathrm{mM})$ was also included in this study. Results were expressed as mean $\pm \mathrm{SD}(\mathrm{n}=3)$ and plotted as percentage normalised cell viability. Data were analysed using paired and unpaired t-tests (see Section 4.9) and statistically significant differences between groups of data ( $p<$ $0.05)$ are indicated by $\star$ which denotes a significant difference from non-irradiated cells (dark).

\section{Conclusion}

We have developed an efficient, modular synthesis of a peptide-targeted prodrug for delivery of multiple ALA copies to a selected cell type. The designed ALA prodrug provides an enhanced release of PpIX compared to equimolar concentrations of free ALA, and a correspondingly enhanced PDT activity. The synthetic strategy developed allows for the efficient targeted delivery of different payloads of ALA to a given cell type by modification of the dendron units or simple variation of the peptide component. This should open up a range of applications for such molecules for both PDT and fluorescence diagnosis applications. 


\section{Materials and Methods}

\subsection{Abbreviations}

Age-related macular degeneration (AMD); aminolevulinic acid (ALA); European Medicines Agency (EMA); epidermal growth factor receptor, EGFR; US Food and Drug Administration (FDA); fluorescence photodiagnosis (PDD); photodynamic therapy (PDT); protoporphyrin IX (PpIX).

\subsection{Chemicals}

Chemical reagents were purchased from Sigma, Aldrich, Fluka, Acros and Novabiochem. Anhydrous DCM was obtained by distillation over calcium hydride. Peptide grade DMF was purchased from Rathburn Chemicals. All other solvents were purchased from Fisher Scientific. Analytical TLC was performed using silica gel $60 \mathrm{~F}_{254}$ pre-coated on aluminium sheets $\left(0.25 \mathrm{~mm}\right.$ thickness) and reverse-phase analytical TLC was performed with RP-18 $\mathrm{F}_{254 \mathrm{~s}}$ pre-coated on aluminium sheets $(0.27 \mathrm{~mm}$ thickness). Column chromatography was performed on silica gel 60 (35-70 micron) from Fisher Scientific.

\subsection{Instruments}

Melting points were recorded on an Electrothermal IA9200 melting point apparatus in open capillaries, and are quoted uncorrected. IR spectra were recorded on a Perkin-Elmer 782 infra-red spectrometer and values are given in $\mathrm{cm}^{-1} .{ }^{1} \mathrm{H}$ and ${ }^{13} \mathrm{C}$ NMR spectra were recorded using a Bruker Advance DPX 500MHz FT and Varian Mercury VX 400MHz spectrometers. $J$ values are given in Hz. Mass spectrometry was performed using a microTOF instrument from Bruker Daltonics (Bremen, Germany). Microwave irradiations were carried out using a Biotage ${ }^{\circledR}$ Initiator microwave instrument. Time-course fluorescence studies were carried out on a CLARIOstar high performance multimode microplate reader (CLARIOstar ${ }^{\circledR}$, BMG LABTECH, United Kingdom). PDT studies were conducted using a Sellas UVA lamp (Gevelsberg, Germany) [64] with a peak emission at $405 \mathrm{~nm}$ and $20 \mathrm{mWcm}^{-2}$ output. Analytical RP-HPLC was performed on a Dionex Ultimate 3000 system (Dionex, UK), with a VWD-3400 variable wavelength detector. Analyses were performed at $35 \pm$ $0.1{ }^{\circ} \mathrm{C}$ on a Gemini $5 \mu \mathrm{m} \mathrm{C18} 110 \mathrm{~A}$ column, (150 x $4.6 \mathrm{~mm}$ - Phenomenex, UK), equipped with a SecurityGuard C18 (ODS) 4 x $3.0 \mathrm{~mm}$ ID guard column (Phenomenex, UK), at a flow rate of $1 \mathrm{~mL} / \mathrm{min}$. Semi-preparative RP-HPLC was performed on a Dionex HPLC system equipped with a Phenomenex Gemini $5 \mu \mathrm{m} \mathrm{C}-18$ (250 x $10 \mathrm{~mm})$ column with a flow rate of $2.5 \mathrm{~mL} \mathrm{~min}^{-1}$. Mobile phase A was $0.1 \%$ TFA in water and mobile phase B was $0.1 \%$ TFA in MeCN. (Method 1: 0.0-10.0 $\min 0-95 \%$ B, 10.0-15.0 $\min 95 \%$ B, 15.0-15.1 min at 95-5\% B, 15.1-18.0 min 5\% B. Method 2: 0.0-10.0 $\min 0-95 \% B, 10.0-20.0 \min 95 \% B, 20.0-20.1 \mathrm{~min}$ at $95-5 \% \mathrm{~B}, 20.1-23.0 \mathrm{~min} 5 \% \mathrm{~B}$ ).

\subsection{Compound synthesis}

\section{$N$-[1,3-Dihydroxy-2-(hydroxymethyl)propan-2-yl]pent-4-ynamide (2)}

A solution of $1(0.75 \mathrm{~g}, 6.20 \mathrm{mmol})$ and EEDQ (1.68 g, $6.75 \mathrm{mmol})$ in EtOH (28 mL) was treated with 4-pentynoic acid $(0.55 \mathrm{~g}, 5.60 \mathrm{mmol})$. The reaction mixture stirred at $65{ }^{\circ} \mathrm{C}$ for $20 \mathrm{~h}$ under $\mathrm{N}_{2}$ and the solvent was evaporated to give the crude product (2.05 g). Purification by column chromatography on silica gel eluting with 1-10\% MeOH in EtOAc gave 2 as a white solid $(0.75 \mathrm{~g}, 66 \%) . \mathrm{Mp}=182-184{ }^{\circ} \mathrm{C} ; \mathrm{R}_{\mathrm{f}}=0.48(10 \% \mathrm{MeOH}$ in EtOAc); $\mathrm{IR}(\mathrm{KBr} \operatorname{disc}) 3420-3230(\mathrm{OH})$, $2931(\mathrm{CH}), 2118(\mathrm{C} \equiv \mathrm{C}), 1627(\mathrm{CO}) ;{ }^{1} \mathrm{H}$ NMR (400 MHz, CD $\mathrm{CD}_{3} \mathrm{O}$ 2.33-2.36 (m, 1H), 2.51-2.56 (m, 4H), 3.79 (s, $\left.6 \mathrm{H}\right)$; 
${ }^{13} \mathrm{C}$ NMR $\left(100 \mathrm{MHz}, \mathrm{CD}_{3} \mathrm{OD}\right) \delta 15.62,36.40,62.49,63.68,70.28,83.56,175.01$; [Found (ESI+) 224.0929 [M+Na] ${ }^{+}$, $\mathrm{C}_{9} \mathrm{H}_{15} \mathrm{NO}_{4} \mathrm{Na}$ requires 224.0893].

3-(\{5-[(tert-Butoxycarbonyl) amino]-4-oxopentanoyl $\}$ oxy $)-2-[(\{5-[($ tert-butoxycarbonyl) amino $]-4-o x o p e n t a n o y l\}$ oxy) methyl]-2-(pent-4-ynoylamino) propyl 5-[(tert-butoxycarbonyl) amino]-4-oxopentanoate (4)

A solution of $2(0.05 \mathrm{~g}, 0.23 \mathrm{mmol})$ in DCM $(15 \mathrm{~mL})$ was treated with $\mathbf{3}(0.20 \mathrm{~g}, 0.93 \mathrm{mmol})$ and DMAP $(0.01 \mathrm{~g}, 0.09$ mmol). The reaction mixture was cooled in an ice bath for $10 \mathrm{~min}$ and EDC.HCl $(0.20 \mathrm{~g}, 1.03 \mathrm{mmol})$ was added. The reaction mixture was stirred under $\mathrm{N}_{2}$ for $48 \mathrm{~h}$ at $30{ }^{\circ} \mathrm{C}$, then the solvent was evaporated and the residue was dissolved in a mixture of EtOAc/ $\mathrm{H}_{2} \mathrm{O}(80 \mathrm{~mL}, 1: 1)$. The organic layer was washed with $5 \%$ aq. citric acid $(1 \mathrm{x} 40 \mathrm{~mL}), 10 \%$ aq. $\mathrm{NaHCO}_{3}(40 \mathrm{~mL})$, brine $(40 \mathrm{~mL})$ and dried over $\mathrm{MgSO}_{4}$. The organic extract was filtered, and the solvent was evaporated to give the crude product as a yellowish oil $(0.20 \mathrm{~g})$. Purification by column chromatography on silica gel eluting with 70-100\% acetone in DCM gave 4 as a yellowish oil (0.18 g, 89\%); $\mathrm{R}_{\mathrm{f}}=0.70$ (30\% acetone in DCM); IR (film) $3373(\mathrm{NH})$, $2979(\mathrm{CH}), 2931(\mathrm{CH}) 2129(\mathrm{C} \equiv \mathrm{C}) ;{ }^{1} \mathrm{H}$ NMR $\left(400 \mathrm{MHz}, \mathrm{CDCl}_{3}\right) \delta 1.40 \quad(\mathrm{~s}, 27 \mathrm{H}), 2.01(\mathrm{t}, J=2.6,1 \mathrm{H}), 2.36-2.39(\mathrm{~m}$, $2 \mathrm{H}), 2.43-2.46(\mathrm{~m}, 2 \mathrm{H}), 2.58-2.61(\mathrm{~m}, 6 \mathrm{H})$ 2.68-2.72 (m, 6H), 3.98-4.00 (m, 6H), $4.36(\mathrm{~s}, 6 \mathrm{H}), 5.33(\mathrm{~s}, 3 \mathrm{H}), 6.33(\mathrm{~s}, 1 \mathrm{H})$; ${ }^{13} \mathrm{C}$ NMR $\left(100 \mathrm{MHz}, \mathrm{CDCl}_{3}\right) \delta 14.66,25.04,27.63,27.88,28.30,34.23,35.52,50.16,58.20,58.26,62.46,69.32,79.94$, 82.98, 155.78, 171.53, 171.87, 204.51; [Found (ESI+) $841.4070[\mathrm{M}+\mathrm{H}]^{+}, \mathrm{C}_{39} \mathrm{H}_{61} \mathrm{~N}_{4} \mathrm{O}_{16}$ requires 841.4077].

\section{Dend-(Tris-ALA-Boc) 3 (6)}

A solution of $5(10.0 \mathrm{mg}, 15.5 \mu \mathrm{mol})$ and $4(78.6 \mathrm{mg}, 93.5 \mu \mathrm{mol})$ in $\mathrm{DMSO} / \mathrm{H}_{2} \mathrm{O}(9: 1,2 \mathrm{~mL})$ was treated with $1 \mathrm{M}$ aq. $\mathrm{CuSO}_{4}(0.14 \mathrm{~mL}, 0.14 \mathrm{mmol})$ and sodium ascorbate $(108 \mathrm{mg}, 0.55 \mathrm{mmol})$ were added. The reaction was stirred for $72 \mathrm{~h}$ at RT and monitored by analytical HPLC (Gradient 1) which showed complete disappearance of $\mathbf{5}$ and formation of new species at $10.53 \mathrm{~min}$. The reaction mixture was purified by semi-preparative HPLC (Gradient 2) to obtain $\mathbf{6}$ as white solid (24.5 mg, 50\%); Analytical HPLC (Gradient 1) Rt = $10.53 \mathrm{~min}$;

${ }^{1} \mathrm{H}$ NMR $\left(500 \mathrm{MHz}, \mathrm{CD}_{3} \mathrm{OD}\right) \delta 1.43(\mathrm{~s}, 81 \mathrm{H})$, 2.55-2.61 (m, 24H), 2.72-2.79 (m, 18H), 2.92-2.94 (m, 6H), 3.58-3.68 (m, 12H), 3.73-3.76 (m, 2H), 3.82-3.93 (m, 28H), 4.19-4.22 (m, 6H), 4.35 (s, 18H), 4.52-4.57 (m, 6H), $7.35(\mathrm{~s}, 2 \mathrm{H}), 7.82-7.84(\mathrm{~m}, 3 \mathrm{H}) ;{ }^{13} \mathrm{C} \mathrm{NMR}\left(125 \mathrm{MHz}, \mathrm{CD}_{3} \mathrm{OD}\right)$ 24.21, 28.59, 28.77, 35.01, 36.30, 50.75, 51.60, 59.17, 63.18, 70.11, 70.39, 70.81, 71.53, 73.68, 80.61, 110.10, 124.83, 127.01, 143.56, 158.41, 169.17, 173.64, 174.76, 207.40; [Found (ESI+) 1604.2249 [M+2H] $]^{2+}, \mathrm{C}_{142} \mathrm{H}_{219} \mathrm{~N}_{21} \mathrm{O}_{59}$ requires 1604.2283].

\section{Dend-(Tris-ALA) 3 .9TFA (7)}

A solution of $6(20 \mathrm{mg}, 6.32 \mu \mathrm{mol})$ in DCM $(5 \mathrm{~mL})$ was treated with TFA $(5 \mathrm{~mL})$ at $0{ }^{\circ} \mathrm{C}$ and the reaction mixture was stirred for $30 \mathrm{~min}$ and monitored by HPLC (Gradient 1 ) which showed complete disappearance of starting material 6 . The solvent was evaporated under vacuum and the residue was co-evaporated with $\mathrm{Et}_{2} \mathrm{O}$ (x 3) to remove excess TFA. This material was freeze dried from $\mathrm{H}_{2} \mathrm{O}$ to give $7(17.5 \mathrm{mg}, 88.0 \%)$; Analytical HPLC (Gradient 1$) \mathrm{Rt}=4.35 \mathrm{~min} ; \quad{ }^{1} \mathrm{H}$ NMR (400 MHz, CD $\left.\mathrm{CD}_{3} \mathrm{OD}\right) \delta 2.61(\mathrm{t}, J=7.4,6 \mathrm{H}), 2.70(\mathrm{t}, J=8.0,18 \mathrm{H}), 2.89(\mathrm{t}, J=8.0,18 \mathrm{H}), 2.95(\mathrm{t}, J=7.4,6 \mathrm{H}), 3.61$ $3.73(\mathrm{~m}, 12 \mathrm{H}), 3.75-3.80(\mathrm{~m}, 2 \mathrm{H}), 3.83-3.92(\mathrm{~m}, 10 \mathrm{H}), 4.08(\mathrm{~s}, 18 \mathrm{H}), 4.19-4.27(\mathrm{~m}, 6 \mathrm{H}), 4.42(\mathrm{~s}, 18 \mathrm{H}), 4.52-4.59(\mathrm{~m}$, $6 \mathrm{H}), 7.40$ (s, 2H), 7.81-7.83 (m, 3H); ${ }^{13} \mathrm{C}$ NMR (125 MHz, CD $\left.{ }_{3} \mathrm{OD}\right)$ 22.22, 28.28, 35.27, 36.45, 48.10, 51.29, 51.37, 59.12, 63.32, 69.98, 70.44, 70.76, 71.29, 71.47, 71.59, 71.70, 73.64, 110.04, 124.38, 127.31, 143.13, 147.57, 153.60, 169.20, 173.55, 175.05, 203.24; [Found (ESI+) $839.1056[\mathrm{M}+3 \mathrm{H}]^{3+}, \mathrm{C}_{97} \mathrm{H}_{149} \mathrm{~N}_{21} \mathrm{O}_{41}$ requires 839.1033].

\section{H-Leu-Ala-Arg(Pmc)-Leu-Leu-Thr(tBu)-2-Chlorotrityl resin (8)}

2-Chlorotrityl resin $(0.5 \mathrm{~g}, 1.3 \mathrm{mmol} / \mathrm{g})$ was pre-swollen in a SPPS vessel using DCM (5 mL) for $15 \mathrm{~min}$, and the procedure was repeated twice. Pre-loading of the first amino acid was accomplished by adding a solution of Fmoc$\mathrm{Thr}(\mathrm{tBu})-\mathrm{OH}(0.775 \mathrm{~g}, 1.95 \mathrm{mmol})$ and DIEA $(0.69 \mathrm{~mL}, 3.9 \mathrm{mmol})$ in DMF $(2 \mathrm{~mL})$. The vessel was agitated for $1 \mathrm{~h}$ and 
the solvent was removed under reduced pressure. The resin was washed with DMF $(5 \mathrm{~mL})$, then piperidine/DMF ( $3 \mathrm{~mL}$, 1:4 $\mathrm{v} / \mathrm{v}$ ) was added to the resin and the vessel was agitated for $5 \mathrm{~min}$. The procedure was repeated and the vessel was shaken for $10 \mathrm{~min}$. The solvent was removed under reduced pressure and the resin was washed with DMF ( $5 \mathrm{x} 5 \mathrm{~mL}$ ). Successful removal of the Fmoc group was confirmed by the Kaiser test. The remaining amino acids were coupled using an Activotec automated peptide synthesiser using 3 eq of Fmoc-protected amino acid (Fmoc-Leu-OH, Fmoc-Arg(Pmc)$\mathrm{OH}$, or Fmoc-Ala-OH), 3 eq of PyBOP as coupling agent, 6 eq of DIEA as base and DMF $(6.0 \mathrm{~mL})$ as solvent. The peptide resin was washed thoroughly with DMF $(2 \times 5.0 \mathrm{~mL}), \mathrm{DCM}(2 \times 5.0 \mathrm{~mL}), \mathrm{MeOH}(5.0 \mathrm{~mL}) \mathrm{and}_{2} \mathrm{O} \quad(2 \times 5.0$ $\mathrm{mL})$, and dried in vacuo to give $8(1.3 \mathrm{~g})$ of peptide resin. The final loading of the peptide was found to be $0.745 \mathrm{mmol} / \mathrm{g}$ by Fmoc loading test.

\section{H-Leu-Ala-Arg-Leu-Leu-Thr-OH. 2TFA (9)}

Peptide resin $8(100 \mathrm{mg}, \mathrm{mmol} / \mathrm{g})$ was placed in a $5 \mathrm{~mL}$ vial and was treated with TFA/TIS/ $\mathrm{H}_{2} \mathrm{O}(2 \mathrm{~mL}, 95: 2.5: 2.5 \mathrm{v} / \mathrm{v} / \mathrm{v})$ for $3 \mathrm{~h}$ at RT. The resin beads were filtered off, washed with TFA, and the combined filtrates were collected into a Falcon tube containing $\mathrm{Et}_{2} \mathrm{O}(5.0 \mathrm{~mL})$ to precipitate the peptide. The resulting precipitate was collected by centrifugation and was washed repeatedly with $\mathrm{Et}_{2} \mathrm{O}$ to remove excess TFA. The precipitated material was dissolved in $0.1 \%$ aq. TFA, filtered using a $0.2 \mu \mathrm{m}$ syringe filter and the resulting solution was directly purified by semi-preparative HPLC (Gradient 1). The purified peptide was then freeze-dried from $\mathrm{H}_{2} \mathrm{O}$ to give 9 as a white solid (55 mg, 85\%); Analytical HPLC (Gradient 1) $\mathrm{R}_{\mathrm{t}}=5.27 \mathrm{~min} ;{ }^{1} \mathrm{H}$ NMR $\left(500 \mathrm{MHz}, \mathrm{CD}_{3} \mathrm{OD}\right) \delta$ 0.93-1.04 (m, 18H), $1.18(\mathrm{~d}, J=6.0,3 \mathrm{H}), 1.41(\mathrm{~d}, J=7.0$, $3 \mathrm{H}), 1.63-1.79(\mathrm{~m}, 12 \mathrm{H}), 1.85-1.92(\mathrm{~m}, 1 \mathrm{H}), 3.21(\mathrm{t}, J=7.0,2 \mathrm{H}), 3.90-3.92(\mathrm{~m}, 1 \mathrm{H}), 4.32-4.50(\mathrm{~m}, 6 \mathrm{H}) ;{ }^{13} \mathrm{C} \mathrm{NMR}(125$ $\left.\mathrm{MHz}, \mathrm{CD}_{3} \mathrm{OD}\right) \quad \delta 17.99,20.55,21.86,21.99,22.05,23.15,23.47,25.35,25.81,25.88,25.96,30.19,41.70,41.72$, 41.97, 42.03, 50.53, 52.83, 53.18, 53.40, 53.95, 58.97, 68.44, 158.65, 170.57, 173.36, 173.47, 174.33, 174.89; [Found (ESI+) $686.4605[\mathrm{M}+\mathrm{H}]^{+}, \mathrm{C}_{31} \mathrm{H}_{60} \mathrm{~N}_{9} \mathrm{O}_{8}$ requires 686.4559].

\section{Azido PEG Gallic acid spacer-H-Leu-Ala-Arg(Pmc)-Leu-Leu-Thr(tBu)-2-Chlorotrityl resin (10)}

Peptide resin $8(115 \mathrm{mg}, 65.5 \mu \mathrm{mol})$ was swollen in DCM $(3.0 \mathrm{~mL})$ for $10 \mathrm{~min}$ and then in DMF $(3 \times 3.0 \mathrm{~mL})$ for $5 \mathrm{~min}$. A solution of $5(84.0 \mathrm{mg}, 131 \mu \mathrm{M})$ in DMF $(400 \mu \mathrm{L})$ was treated with HATU $(49.0 \mathrm{mg}, 131 \mu \mathrm{mol})$ followed by DIEA ( $45.0 \mu \mathrm{L}, 262 \mu \mathrm{mol}$ ). After $3 \mathrm{~min}$ of preactivation, the mixture was added to the peptide resin. The resin was shaken for $24 \mathrm{~h}$, then the solvent was removed and the resin beads were washed with DMF ( $3 \times 2.0 \mathrm{~mL}), \mathrm{DCM}(3 \times 2.0 \mathrm{~mL}), \mathrm{MeOH}$ $(2.0 \mathrm{~mL})$ and DCM $(2 \times 2.0 \mathrm{~mL})$. Successful attachment of $\mathbf{1 0}$ was confirmed by a negative Kaiser test.

\section{Azido PEG Gallic acid spacer-H-Leu-Ala-Arg-Leu-Leu-Thr-OH. TFA (11)}

Peptide resin $10(50 \mathrm{mg}, 37.7 \mu \mathrm{mol})$ was placed in a $3 \mathrm{~mL}$ vial and was treated with TFA/TIS/ $\mathrm{H}_{2} \mathrm{O}(1 \mathrm{~mL}, 95: 2.5: 2.5$ $\mathrm{v} / \mathrm{v} / \mathrm{v}$ ) for $3 \mathrm{~h}$ at RT. The resin beads were filtered off, washed with TFA, and the combined filtrates were collected into a Falcon tube containing $\mathrm{Et}_{2} \mathrm{O}(5.0 \mathrm{~mL})$ to precipitate the peptide. The resulting precipitate was collected by centrifugation and was washed repeatedly with $\mathrm{Et}_{2} \mathrm{O}$. The precipitated material was dissolved in $0.1 \%$ aq. TFA, filtered using a $0.2 \mu \mathrm{m}$ syringe filter and the resulting solution was purified by semi-preparative HPLC (Gradient 2). The purified peptide was then freeze-dried from $\mathrm{H}_{2} \mathrm{O}$ to give $\mathbf{1 1}$ as the TFA salt (29 mg, 54\%); Analytical HPLC (Gradient 1) $\mathrm{R}_{\mathrm{t}}=8.44$ min; ${ }^{1} \mathrm{H}$ NMR $\left(500 \mathrm{MHz}, \mathrm{CD}_{3} \mathrm{OD}\right) \delta$ 0.90-1.02 (m, 18H), $1.18(\mathrm{~d}, J=6.5,3 \mathrm{H}), 1.38(\mathrm{~d}, J=7.0,3 \mathrm{H}), 1.63-1.79(\mathrm{~m}, 12 \mathrm{H}), 1.87-$ $1.94(\mathrm{~m}, 1 \mathrm{H}), 3.16-3.19(\mathrm{~m}, 2 \mathrm{H}), 3.34-3.38(\mathrm{~m}, 6 \mathrm{H}), 3.63-3.69(\mathrm{~m}, 12 \mathrm{H}), 3.71-3.75(\mathrm{~m}, 6 \mathrm{H}), 3.81-3.85(\mathrm{~m}, 2 \mathrm{H}), 3.87-3.92$ $(\mathrm{m}, 4 \mathrm{H}), 4.21-4.36(\mathrm{~m}, 9 \mathrm{H}), 4.38-4.42(\mathrm{~m}, 2 \mathrm{H}), 4.45-4.51(\mathrm{~m}, 2 \mathrm{H}), 7.25(\mathrm{~s}, 2 \mathrm{H}) ;{ }^{13} \mathrm{C} \mathrm{NMR}\left(125 \mathrm{MHz}, \mathrm{CD}_{3} \mathrm{OD}\right) \delta 17.44$, 20.49, 21.76, 21.82, 22.21, 23.34, 23.54, 23.57, 25.77, 25.92, 26.00, 26.11, 29.89, 41.38, 41.63, 41.70, 41.94, 51.26, $51.79,53.32,53.48,54.27,54.82,59.04,68.58,70.25,70.94,71.15,71.62,71.65,71.89,73.65,108.37,153.84,173.29$, 173.90, 174.85; [Found (ESI+) 677.3840 [M+2Na] ${ }^{2+}, \mathrm{C}_{56} \mathrm{H}_{96} \mathrm{~N}_{18} \mathrm{O}_{18} \mathrm{Na}_{2}$ requires 677.3467]. 


\section{Dend-(Tris-ALA) 3 -LARLLT-OH. 10TFA (13) \\ Click coupling AT RT}

A solution of peptide-targeted core unit $11(5 \mathrm{mg}, 3.55 \mu \mathrm{mol})$ in DMSO (100 $\mu \mathrm{L})$ was treated with $4(18 \mathrm{mg}, 21 \mu \mathrm{mol})$ and copper(I) trifluoromethanesulfonate benzene complex $(11 \mathrm{mg}, 21 \mu \mathrm{mol})$, and the reaction mixture was stirred for 36 $\mathrm{h}$ and monitored by analytical HPLC (Gradient 1 ) which showed the disappearance of the starting material and appearance of new species at $9.94 \mathrm{~min}$. The reaction mixture was diluted with $0.1 \%$ aq. TFA and the product was isolated by semipreparative HPLC (Gradient 2) and freeze-dried from $\mathrm{H}_{2} \mathrm{O}$ to give Boc-protected peptide-targeted dendrimer 12 (9.5 mg, $69 \%)$.

\section{Under microwave irradiation}

A solution of peptide-targeted core unit 11 (5 mg, $3.55 \mu \mathrm{mol})$ in DMSO (100 $\mu \mathrm{L})$ was treated with 4 (18 mg, $21 \mu \mathrm{mol})$ and copper(I) trifluoromethanesulfonate benzene complex $(11 \mathrm{mg}, 21 \mu \mathrm{mol})$, and the reaction was carried out in a microwave (MW) reaction vial (Biotage Initiator Microwave reactor) which was irradiated for 10 min (at constant power, $10-15 \mathrm{~W}$; temp $=70^{\circ} \mathrm{C}$ ). The reaction was allowed to reach RT and the vial was removed from the MW cavity. The reaction mixture was analysed by HPLC (Gradient 1) which showed complete disappearance of the starting material 11 and formation of a new species at $9.94 \mathrm{~min}$. The product was isolated by semi-preparative HPLC and freeze-dried from $\mathrm{H}_{2} \mathrm{O}$ to give the Boc-protected peptide-targeted dendrimer $12(10.3 \mathrm{mg}, 75 \%)$. Analytical HPLC $($ Gradient 1$) \mathrm{R}_{\mathrm{t}}=9.94$ min; [Found (ESI+) $1915.9682[\mathrm{M}+2 \mathrm{H}]^{2+}, \mathrm{C}_{173} \mathrm{H}_{278} \mathrm{~N}_{30} \mathrm{O}_{66}$ requires 1915.9654]. The resulting product 12 was dissolved in dry DCM (3 mL) and the reaction mixture cooled to $0{ }^{\circ} \mathrm{C}$. TFA $(3 \mathrm{~mL})$ was added dropwise and the reaction mixture stirred for $30 \mathrm{~min}$ at RT and monitored by analytical HPLC (Gradient 1) which showed complete disappearance of 12 and appearance of new species at $5.18 \mathrm{~min}$. The solvent was evaporated under reduced pressure and the residue was coevaporated with $\mathrm{Et}_{2} \mathrm{O}$ (x 3) to remove excess TFA. This material was freeze dried from $\mathrm{H}_{2} \mathrm{O}$ to give final product $\mathbf{1 3}$ as a white solid (9.1 mg, 95\%); Analytical HPLC (Gradient 1) $\mathrm{R}_{\mathrm{t}}=5.18 \mathrm{~min} ;{ }^{1} \mathrm{H}$ NMR (500 MHz, CD $\left.{ }_{3} \mathrm{OD}\right) \delta 0.92-0.94(\mathrm{~m}$, $6 \mathrm{H}), 0.97-1.03(\mathrm{~m}, 12 \mathrm{H}), 1.19-1.23(\mathrm{~m}, 3 \mathrm{H}), 1.38-1.43(\mathrm{~m}, 3 \mathrm{H}), 1.66-1.85(\mathrm{~m}, 12 \mathrm{H}), 1.92-1.95(\mathrm{~m}, 1 \mathrm{H}), 2.61(\mathrm{t}, J=7.5$, $6 \mathrm{H}), 2.68-2.73(\mathrm{~m}, 18 \mathrm{H}), 2.87-2.91(\mathrm{~m}, 18 \mathrm{H}), 2.94(\mathrm{t}, J=7.0,6 \mathrm{H}), 3.21(\mathrm{t}, J=7.0,2 \mathrm{H}), 3.64-3.70(\mathrm{~m}, 12 \mathrm{H}), 3.74-3.79$ $(\mathrm{m}, 2 \mathrm{H}), 3.84-3.87(\mathrm{~m}, 4 \mathrm{H}), 3.88-3.92(\mathrm{~m}, 6 \mathrm{H}), 4.08(\mathrm{~s}, 18 \mathrm{H}), 4.18-4.21(\mathrm{~m}, 2 \mathrm{H}), 4.22-4.25(\mathrm{~m}, 4 \mathrm{H}), 4.28-4.31(\mathrm{~m}, 1 \mathrm{H})$, 4.33-4.37 (m, 2H), 4.38-4.45 (m, 20H), 4.46-4.52 (m, 1H), 4.54-4.59 (m, 7H), 7.29-7.33 (m, 2H), 7.79-7.83 (m, 3H); ${ }^{13} \mathrm{C}$ NMR (125 MHz, CD $\left.{ }_{3} \mathrm{OD}\right) \delta 17.50,20.50,21.78,22.23,23.38,23.56,23.60,25.75,25.91,26.09,28.27,35.31,36.46$, 41.34, 41.61, 41.94, 48.14, 51.25, 51.32, 53.36, 53.61, 54.50, 54.85, 59.10, 63.29, 68.57, 69.97, 70.44, 70.73, 71.28, 71.43, 71.57, 71.65, 73.63, 108.08, 124.32, 147.59, 153.66, 158.58, 173.47, 173.55, 174.94, 175.08, 203.26; [Found (ESI+) $977.4865[\mathrm{M}+3 \mathrm{H}]^{3+}, \mathrm{C}_{128} \mathrm{H}_{204} \mathrm{~N}_{30} \mathrm{O}_{48}$ requires 977.4888].

\subsection{Cell lines and cultivation}

Cell culturing was carried out in 10\% FCS DMEM (high glucose Dulbecco's modified Eagle's medium) with 30 mM $\mathrm{NaHCO}_{3}, 2 \mathrm{mM}$ L-glutamine, and $50 \mathrm{IU} / \mathrm{mL}$ of each of penicillin/ streptomycin. The FCS stock was heat-inactivated at $56{ }^{\circ} \mathrm{C}$ for 45 min before use. Cells were passaged once every 5 days and seeded at a density of $8 \times 10^{3}$ cells per well in media $(200 \mu \mathrm{L})$, and grown for $24 \mathrm{~h}$ prior to the treatment with compounds for 4 or $24 \mathrm{~h}$, depending on the experimental requirement.

\subsection{Time course fluorescence studies}

Cells were seeded into clear 96-well cell culture micro-plates (CELLSTAR ${ }^{\circledR}$, Greiner Bio-one, United Kingdom) at a 
density of $8 \times 10^{3}$ cells per well for $24 \mathrm{~h}$. The culture medium was removed and each well was washed with PBS ( $2 \times 100$ $\mu \mathrm{L})$. Varying concentrations of ALA and ALA-containing prodrugs in phenol red $(100 \mu \mathrm{L})$ and serum-free medium (100 $\mu \mathrm{L}$ ) were then added to designated series of wells in triplicates under subdued lighting. Each plate contained control wells with cells but without added drug to determine the background reading. Each plate was covered with aluminium foil and placed in the incubator at $37{ }^{\circ} \mathrm{C} \mathrm{CO}_{2}$ for 4-24 h. The fluorescence signal from each well was measured at 4,8 and $\mathrm{h}$ interval with a CLARIOstar high performance microplate reader using $410 \mathrm{~nm}$ excitation and $635 \mathrm{~nm}$ emission wavelengths with slit widths set to $10 \mathrm{~nm}$.

\subsection{Cytotoxicity and MTT assay}

Cells were seeded into 96-well black cell culture micro-plates (CELLSTAR ${ }^{\circledR}$, Greiner Bio-one, United Kingdom) at a density of $8 \times 10^{3}$ cells per well for $24 \mathrm{~h}$. The culture medium was removed and each well was washed with PBS ( $2 \times 100$ $\mu \mathrm{L})$. Varying concentrations of ALA and ALA-containing prodrugs in phenol red and serum-free medium (100 $\mu \mathrm{L})$ were then added to designated series of wells in triplicates under subdued lighting. Each plate contained control wells with cells but without added drug to determine the background reading. Each plate was covered with aluminium foil and placed in the incubator for $4 \mathrm{~h}$ at $37^{\circ} \mathrm{C}$ under an atmosphere of $5 \% \mathrm{CO}_{2}$. After $4 \mathrm{~h}$, drug samples were removed and PBS (100 $\mu \mathrm{L})$ was added to each well. The plates were irradiated from above using a Sellas UVA lamp for 30, 60 and $90 \mathrm{~s}(0.6$, 1.2 and $1.8 \mathrm{~J} / \mathrm{cm}^{2}$ - see 4.3 Instruments) by moving a box covered with foil across the plate to expose the appropriate wells. After the irradiation, the PBS was replaced with serum-free medium and plates were incubated for further $48 \mathrm{~h}$ and the cell viability was assessed using MTT assay. Prior to the experiment, a solution of MTT in serum free medium (SFM) was prepared at a final concentration of $0.5 \mathrm{mg} / \mathrm{mL}$ from the stock solution. 96 well plates were removed from the incubator and SFM from each well was replaced with MTT/SFM solution $(100 \mu \mathrm{L})$. The plates were then incubated for a further $3 \mathrm{~h}$. The MTT/SFM solution was removed and DMSO $(100 \mu \mathrm{L})$ was added to each well. The plates were then kept swirling for few minutes on a 3D rocking platform (Stuart Scientific UK) under dim lighting. The DMSO solutions were then transferred to a new 96 well plate (transparent) and read with a Dynatech plate reader MR-5000 (Dynatech, Guernsey, Channel Islands) at $570 \mathrm{~nm}$ using DMSO as a blank control. The mean values obtained from the raw data for each condition were expressed as percentage cell viability.

\subsection{Statistical analysis}

Results were expressed as mean +/- standard deviation (SD). Data were analysed using paired and unpaired t-tests. The $p$ value of $<0.05$ was considered as a significant difference between groups of data. GraphPad Prism 7.01 and Microsoft Excel 2013 software was used to carry out statistical analysis. The ranges given to the number of experiments for each graph presented in the Results section (i.e. $\mathrm{n}=3,4$ or 6 ), indicates the number of independent experiments carried out with different compounds/treatments.

\section{Declaration of competing interests}

The authors declare that they have no known competing financial interests or personal relationships that could have appeared to influence the work reported in this paper. 


\section{Acknowledgements}

This work was supported by BBSRC grants BB/J009164/1 (IME) and BB/J009318/1 (AJM). We thank the University of Bath Faculty of Science for a Fee Waiver Scholarship (KMT). We thank Prof. S. Pascu and Dr F. Cortezon Tamarit for assistance with the microwave synthesis.

\section{Appendix A. Supplementary material}

These data include ${ }^{1} \mathrm{H},{ }^{13} \mathrm{C}$ and MS spectra of all the compounds described in this article.

\section{References}

[1] W. M. Sharman, C. M. Allen and J. E. van Lier, Drug Discovery Today, 1999, 4, 507-517.

[2] A-R Azzouzi, S. Vincendeau, E. Barret, A. Cicco, F. Kleinclauss, H. G. van der Poel, C. G. Stief, J. Rassweiler, G. Salomon, E. Solsona, A. Alcaraz, T. T. Tammela, D. J. Rosario, F. G. Veiga, G. Ahlgren, F. Benzaghou, B. Gaillac, B. Amzal, F. M. J. Debruyne, G. Fromont, C. Gratzke, and M. Emberton, Lancet Oncol., 2017, 18, 181-191.

[3] C. Ferroni, A. Del Rio, C. Martini, E. Manoni and G. Varchi, Front. Chem., 2019, 7, 719.

[4] P. Agostinis, K. Berg, K. A. Cengel, T. H. Foster, A. W. Girotti, S. O. Gollnick, S. M. Hahn, M. R. Hamblin, A. Juzeniene, D. Kessel, M. Korbelik, J. Moan, P. Mroz, D. Nowis, J. Piette, B. C. Wilson and J. Golab, CA Cancer J. Clin., 2011, 61, 250-281.

[5] S. Yano, S. Hirohara, M. Obata, Y. Hagiya, S.-I. Ogura, A. Ikeda, H. Kataoka, M. Tanaka and T. Joh, J. Photochem. Photobiol., C, 2011, 12, 46-67.

[6] B. Krammer and K. Plaetzer, Photochem. Photobiol. Sci., 2008, 7, 283-289.

[7] Z. Malik, Translational Biophotonics, 2020, 2, e201900022.

[8] K. McNicholas, M. N. MacGregor and J. M. Gleadle, Br. J. Cancer, 2019, 121, 631-639.

[9] C. Thunshelle, R. Yin, Q. Chen and M. R. Hamblin, Curr. Dermatol. Rep., 2016, 5, 179-190.

[10] J.E. Räsänen, N. Neittaanmäki, L. Ylitalo, J. Hagman, P. Rissanen, L. Ylianttila, M. Salmivuori, E. Snellman and M. Grönroos, Br. J. Dermatol., 2019, 181, 265-274.

[11] L. J. McLellana, P. O’Mahoney, M. Khazovad, M. Higlett, S. H. Ibbotson and E. Eadie, Photodiag. Photodynam. Ther., 2019, 27, 19-23.

[12] P. O’Mahoney and E. Eadie, Photochem. Photobiol., 2020, 96, 434-436.

[13] S. W. Cramer and C. C. Chen, Front. Surg., 2020, 6, 81.

[14] A. Casas, Cancer Lett., 2020, 490, 165-173.

[15] N. Fotinos, M. A. Campo, F. Popowycz, R. Gurny and N. Lange, Photochem. Photobiol., 2006, 82, 9941015.

[16] D. I. J. Morrow, P. A. McCarron, A. D. Woolfson, P. Juzenas, A. Juzienne, V. Iani, J. Moan and R. F. Donnelly, J. Pharm. Pharmacol., 2010, 62, 906-913.

[17] K. M. Tewari and I. M. Eggleston, Photochem. Photobiol. Sci., 2018, 17, 1553-1572.

[18] S. Sansaloni-Pastor, J. Bouilloux and N. Lange, Pharmaceuticals, 2019, 12, 148.

[19] K. M. Chan, J. Gleadle, K. Vasilev and M. MacGregor, Int. J. Mol. Sci., 2020, 21, 2963.

[20] V. Herceg, N. Lange, E. Allémann and A. Babic, J. Photochem. Photobiol., B, 2017, 171, 34-42.

[21] V. Herceg, S. Adriouach, K. Janikowska, E. Allémann and A. Babic, Bioorg. Chem., 2018, 78, 372-380. 
[22] K. Li, W. Dong, L. Qiu, Q. Liu, G. Lv, Y. Peng, M. Xie and J. Lin, Eur. J. Med. Chem., $2019,181,111582$.

[23] A. Punjabi, X. Wu, A. Tokatli-Apollon, M. El-Rifai, H. Lee, Y. Zhang, C. Wang, Z. Liu, E. M. Chan, C. Duan and G. Han, ACS Nano, 2014, 8, 10621-10630.

[24] J. Wu, H. Han, Q. Jin, Z. Li, H. Li, and J. Ji, ACS Appl. Mater. Interfaces, 2017, 9, 14596-14605.

[25] L. Bourré, F. Giuntini, I. M. Eggleston, M. Wilson and A. J. MacRobert, Mol. Cancer Ther., 2008, 7, 17201729.

[26] L. Bourré, F. Giuntini, I. M. Eggleston, M. Wilson and A. J. MacRobert, Br. J. Cancer, 2009, 100, 723731 .

[27] F. Giuntini, L. Bourré, A. J. MacRobert, M. Wilson and I. M. Eggleston, J. Med. Chem., 2009, 52, 40264037.

[28] G. Di Venosa, P. Vallecorsa, F. Giuntini, L. Mamone, A. Batlle, S. Vanzuli, A. Juarranz, A. J. MacRobert, I. M. Eggleston and A. Casas, Mol. Cancer Ther., 2015, 14, 440-451.

[29] M. J. Dixon, L. Bourré, A. J. MacRobert and I. M. Eggleston, Bioorg. Med. Chem. Lett., 2007, 17, 45184522.

[30] R. P. Johnson, C.-W. Chung, Y.-I. Jeong, D. H. Kang, H. Suh and I. Kim, Int. J. Nanomed., 2012, 7, $2497-$ 2512.

[31] W. R. Abd-Elgaliel, Z. Cruz-Monserrate, H. Wang, C. D. Logsdon and C.-H. Tung, J. Controlled Release, 2013, 167, 221-227.

[32] T. Zhou, L.-L. Shao, S. Battah, C.-F. Zhu, R. C. Hider, B. J. Reeder, A. Jabeen, A. J. MacRobert, G. Ren and X. Liang, Med.Chem.Commun., 2016, 7, 1190-1196.

[33] A. Guaragna, G. N. Roviello, S. D'Errico, C. Paolella, G. Palumbo and D. D'Alonzo, Tetrahedron Lett., 2015, 56, 775-778.

[34] E. E. Kamarulzaman, A. M. Gazzali, S. Acherar, C. Frochot, M. Barberi-Heyob, C. Boura, P. Chaimbault, E. Sibille, H. A. Wahab and R. Vanderesse, Int. J. Mol. Sci., 2015, 16, 24059-24080.

[35] E. Y. Xue, R. C. H. Wong, C. T. T. Wong, W. P. Fong and D. K. P. Ng, RSC Advances, 2019, 9, 2065220662.

[36] S. A. M. Van Lith, D. van den Brand, R. Wallbrecher, L. Wubbeke, S. M. J. van Duijnhoven, P. I. Makinen, J. S. Hoogstad van Evert, L. Massuger, S. Yla-Herttuala, R. Brock and W. P. J. Leenders, Eur. J. Pharm, Biopharm., 2018, 124, 63-72.

[37] R. Dondi, E. Yaghini, K. M. Tewari, L. Wang, F. Giuntini, M. Loizidou, A. J. MacRobert and I. M. Eggleston, Org. Biomol. Chem., 2016, 14, 11488-11501.

[38] E. Yaghini, R. Dondi, K. M. Tewari, M. Loizidou, A. J. MacRobert and I. M. Eggleston, Sci. Rep., 2017, 7, 6059 .

[39] E. Yaghini, R. Dondi, K. J. Edler, M. Loizidou, A. J. MacRobert and I. M. Eggleston, Nanoscale, 2018, 10, 20366-20376.

[40] S. H. Battah, C.-E. Chee, H. Nakanishi, S. Gerscher, A. J. MacRobert and C. Edwards, Bioconjugate. Chem., 2001, 12, 980-988.

[41] S. Battah, S. Balaratnam, A. Casas, S. O'Neill, C. Edwards, A. Batlle, P. Dobbin and A. J. MacRobert, Mol. Cancer Ther., 2007, 6, 876-885. 
[42] S. Battah, S. O'Neill, C. Edwards, S. Balaratnam, P. Dobbin and A. J. MacRobert, Int. J. Biochem. Cell Biol., 2006, 38, 1382-1392.

[43] G. M. Di Venosa, A. G. Casas, S. Battah, P. Dobbin, H. Fukuda, A. J. MacRobert and A. Batlle, Int. J. Biochem. Cell Biol., 2006, 38, 82-91.

[44] A. Casas, S. Battah, G. Di Venosa, P. Dobbin, L. Rodriguez, H. Fukuda, A. Batlle and A. J. MacRobert, J. Controlled Release, 2009, 135, 136-143.

[45] L. Rodriguez, P. Vallecorsa, S. Battah, G. Di Venosa, G. Calvo, L. Mamone, D. Sáenz, M. C. Gonzalez, A. Batlle, A. J. MacRobert and A. Casas, Photochem. Photobiol. Sci., 2015, 14, 1617-1627.

[46] A. François, S. Battah, A. J. MacRobert, L. Bezdetnaya, F. Guillemin and M.-A. D'Hallewin, BJU International, 2012, 110, E1155-E1162.

[47] B. G. Ongarora, K. R. Fontenot, X. Hu, I. Sehgal, S. D. Satyanarayana-Jois and M. G. H. Vicente, J. Med. Chem., 2012, 55, 3725-3738.

[48] K. R. Fontenot, B. G. Ongarora, L. E. LeBlanc, Z. Zhou, S. D. Jois and M. G. H. Vicente, J. Porphyr. Phthalocyanines, 2016, 20, 352-366.

[49] T. M. Williams, R. Sable, S. Singh, M. G. H. Vicente, and S. Jois, Chem. Biol. Drug Des., 2018, 91, 605619.

[50] G. C. Feast, T. Lepitre, X. Mulet, C. E. Conn, O. E. Hutt, G. P. Savage and C. J. Drummond, Beilstein J. Org. Chem., 2014, 10, 1578-1588.

[51] S. P. Amaral, M. Fernandez-Villamarin, J. Correa, R. Riguera and E. Fernandez-Megia, Org. Lett., 2011, 13, 4522-4525.

[52] M. Meldal and C. W. Tornøe, Chem. Rev., 2008, 108, 2952-3015.

[53] S. Song, D. Liu, J. Peng, H. Deng, Y. Guo, L. X. Xu, A. D. Miller and Y. Xu, FASEB J., 2009, 23, 13961404.

[54] E. Kaiser, R. L. Colescott, C. D. Bossinger and P. I. Cook, Anal. Biochem., 1970, 34, 595-598.

[55] Y. L. Angell and K. Burgess, Chem. Soc. Rev., 2007, 36, 1674-1689.

[56] Z. S. Zhang and E. Fan, Tetrahedron Lett., 2006, 47, 665-669.

[57] R. R. Cesati, III, J. de Armas, and A. H. Hoveyda, J. Am. Chem. Soc. 2004, 126, 96-101.

[58] R. C. Elgersma, M. van Dijk, A. C. Dechesne, C. F. van Nostrum, W. E. Hennink, D. T. S. Rijkersa and R. M. J. Liskamp, Org. Biomol. Chem., 2009, 7, 4517-4525.

[59] M. van Dijk, K. Mustafa, A. C. Dechesne, C. F. van Nostrum, W. E. Hennink, D. T. S. Rijkers and R. M. J. Liskamp, Biomacromolecules, 2007, 8, 327-330.

[60] M. van Dijk, M. L. Nollet, P. Weijers, A. C. Dechesne, C. F. v. Nostrum, W. E. Hennink, D. T. S. Rijkers and R. M. J. Liskamp, Biomacromolecules, 2008, 9, 2834-2843.

[61] S. Acherar, L. Colombeau, C. Frochot and R. Vanderesse, Curr. Med. Chem., 2015, 22, $3217-3254$.

[62] M. Reinert, D. Piffaretti, M. Wilzbach, C. Hauger, R. Guckler, F. Marchi and M. L. D’Angelo, Front. Surg. 2019, 6:41.

[63] X. Pudroma, J. Moan, L.-W. Ma, V. Iani and A. Juzeniene, Exp. Dermatol. 2009; 18, $985-987$.

[64] O. Reelfs, R. M. Tyrrell and C. Pourzand, J. Invest. Dermatol. 2004, 122, 1440-1447. 